\title{
Peculiarities of the Genre of Poem in the Literature of the Peoples of the North
}

\author{
Varvara B. Okorokova \\ and Antonina A. Vinokurova* \\ M.K. Ammosov North-Eastern Federal University \\ 58 Belinsky Str., Yakutsk, 677000, Russia
}

Received 12.01.2018, received in revised form 30.03.2018, accepted 03.04.2018

The contribution of the writers of the north to the development of the genre of poem is considered in the article. In the poems by V. Lebedev and Uluro Ado, who became the first poets in the Even and Yukaghir literatures, the epic traditions of the peoples are combined with the achievements of modern Russian literature. Mythological and folklore motives and, generally, interest in the history of native peoples are intensified in the modern poetry of the literature of the peoples of the north. The writers of the north occupy the main place in the preservation and revival of the oral folk art and national culture traditions. But at the same time, the poems of the authors resonate with the problems of mankind, they are relevant and are developing in the mainstream of all modern literature.

Keywords: literature of the peoples of the north, genre, poem, plot, image, folklore traditions.

The article is supported by the grant of the Russian Foundation for Humanities No. 17-06-18020 on the project of the scientific and pedagogical expedition "The Influence of Ethnocultural Traditions of Nomadic Peoples on the Development of the Students' Personality".

DOI: 10.17516/1997-1370-0251.

Research area: literary studies.

Literatures of the peoples of the north, the socalled recently put into writing literatures, started emerging from the 30 s of the $20^{\text {th }}$ century. Herzen State Pedagogical University (Leningrad), where the representatives of the peoples of the north studied, played a huge role in the development of fiction and science. But, nevertheless, during the repressions and the Great Patriotic War, the development of young literatures of the north was interrupted for a long time. The first Even writer N. Tarabukin died young during these cruel years of persecution. The founder of the Yukaghir literature, Teki Odulok, was repressed in 1937, barely having reached his thirtieth birthday. The new impetus for the literatures development was set in the $60 \mathrm{~s}$ at the time of the "Thaw". V. Lebedev, the Even poet and G.N. KurilovUluro Ado, the Yukaghir poet, were the bright representatives of the "Sixtiers". The romantic spirit of their poetry is embodied in their poems, glorifying the significance of the Soviet power in the life of the peoples of the North. In this way a lot of their poems about Lenin, and the changes in the people's life under the influence of

(c) Siberian Federal University. All rights reserved

* Corresponding author E-mail address: bokorsaisar@mail.ru; antonina-vinokurova@bk.ru 
the Great October Revolution appeared. On the other hand, interest in the ancient times and the ancient history of the people, was intensified at this time. To show the life of the people, the poets turn to mythological and folklore traditions and, as a result, they create their amazingly beautiful poems. Ethnographic realias and customs are of interest to historians since the writers are experts in the history of their peoples.

V. Lebedev was a talented Even poet, whose works had a strong poemic core. His main poems are inspired by the plots and images of oral folk art. Poems "Миргилан" and "Ханьан хуен" fictionally recreate the ancient Even telenel - tales and legends. He also wrote poems "Омчэни" (The First), “Бягандя хунадян” (Daughter of the Moon) and "Чирун мэргэн эңтири" (Silly Wood Grouse), which represent creative adaptation of the Even nimkan tales.

Studying the interrelationships of Yakut folklore and modern poetry, N.N. Toburokov revealed a tendency, when "tales and legends were the most popular for the writers in the 30 s and 40s and even later, and modern poets are fonder of ritual poetry" (Toburokov, 1991: 29).

The plot of the poem by V. Lebedev "Омчэни" is typical for the archaic Even epos. It depicts a heroic matchmaking with the motives of finding and getting a wife. An obligatory link (a marvelous feat as the character's trial) is clearly marked out. The Even nimkan refers to the archaic form of fairy tale, the worldview of the ancient people is strongly reflected in it. "... From the point of view of the specificity of the fictional image of the world, ... the Even archaic tale has not lost its connection with the myth and specific "ethnographic nature" (Lebedeva, 1981: 136). This, first of all, is a heroic matchmaking, characteristic of the epics of the Kolyma and Indigirka Evens. Secondly, the motive, according to which "the younger brother gets a bride for the elder brother" is based on the ritual traditions of the people (Lebedeva, 1981: 137).

Once, during the hunting, the character of the poem Omcheni saw swans with white-golden wings, turning into girls and singing songs. Seeing the beautiful girls and deciding to marry one of them, Omcheni asks his younger brother to catch a swan-girl for him. The swans leave their clothing-wings, start dancing khede, and having noticed the young man, they invite him to join them.

The image of an animal - primal forefather occupies a prominent position among the mythological and folklore characters of all the peoples of the world. In the Paleo-Asiatic epos such a character is usually a raven, and the echoes of the existing ancestral bear cult are preserved in the main character of the bear festival. "The image of the ornitho-anthropomorphic primal foremother swan is found not only among the Evenki, Buryats, Yakuts and Kazakhs who preserved the myths about it, but among European peoples, whose folklore recorded fairy stories about the "swan lake" as well" (Reshetnikova, 2005: 340). Mythological, epic and fairy tale plots about the ornitho-anthropomorphic werewolf the swan-girl - are necessarily associated with the lake, on the shore of which the heavenly creatures leave their clothing from the wings that possess the magical properties of transforming their possessor, and bathe in human shape (Reshetnikova, 2005: 377).

The swan-girl abduction is described. Having heard how Irkenme loudly calls his older brother: "Aka-ah!", the frightened swans, putting on their wings, started flying away. But he grabbed one of the girls by the braid and did not let her go, at that time Omcheni wrapped the girl's wings in the mukuli (fur coat). But three years later, after finding her clothes, she flies away. Going to search for his wife, Omcheni turns first into a mouse and then into an ermine. 
And only on the seashore the character sees swans and from their conversation he learns that these birds are sacred and come from the Upper World. Their assistant is the bird Burkan, who is a mythological deity and lives in the Upper World, where the swan girls come from. Burkan convokes all the people who live in the Upper World, and seven days without interruption they do a circle dance - khede. In such a way Omcheni finds his wife. Having received Burkan's blessing Omcheni's family returns to the Middle World. Thus, the author uses all the mythical elements of the fairy tale.

Accordingly, V. Lebedev follows folklore and epic traditions in the poetics of his work. The rhythmics of the poem is characterized by 7 and 9-syllable lines, which is close to the epic poetry. The structure of this poem is also close to the specific features of the Even stories and traditions of the people's songs - each character has his/her own song with introduction: "Гивлинчо икэн” (The Song of Givlincho), "Кэкучэн икэн” (The Song of the Cuckoo), “Эринчу икэн” ("The Song of Erinchu”), “Иркэнмэл икэл” (The Song of Irkenmel), “Чивкачан икэн” (The Song of the Bird), "Хуси хуркэнни икэн" (The Song of the Son of the Swan), "Хуси хунадин икэн" (The Song of the Daughter of the Swan), “Буркан Буран икэн” (The Song of Burkan Buran).

The researcher of the Evenki folklore A.N. Myreeva writes: "The repeated choruses nimnakan are not only typical to legends, but also to myths and shamanic chants. Such introductions - choruses can be observed in the Evenki songs-improvisations and in all circle dances, taking place not only among the Tungus, but also among other peoples. In heroic tales such introductions are the beginning of direct speech. ... a direct speech-song begins with an appeal to the name of a person whom the speech is addressed to. ... the word of appeal is repeated two or three times, they replace the chorus and determine the rhythm of direct speech" (Myreeva, 1980: 93).

The portrait description of the swan-girl is also in the style of folklore chants. The poet used folklore figures of speech: epithets, hyperbolas, repetitions and parallelisms:

\begin{abstract}
Чуриткачин ясалалкан,
Хутав балчин ондэчэлкэн,

Нөлтэн балан талартари

Илан халан илчаралкан,

Мэңэн колач уиргалкан,

Чунганячан дылгалкан,

Чоргутичэн икиритти,

Нилбутари хогналкан,

Нёбатичан бадалкан,

Хедды гяван урэмэкэн

Хулинячан хунэлэлкэн
\end{abstract}

\author{
Her eyes are like beads, \\ scarlet blush on her cheeks, \\ with the fair sunny face, \\ with the thick braid, \\ with golden pendants, \\ with long and beautiful neck, \\ with thin bone, \\ with graceful walk, \\ with c snow-white reflection, \\ as the morning dawn, \\ and scarlet blood [translated by the author of the article-
} A.V.].
Thus, in "Омчэни" the poet creatively uses the elements of the epic legend of the Even folklore. In contrast to epic legends, there is no Lower World in the poem, and in this way the folklore plot is reduced. The main storyline of the epic work is preserved: it is finding a wife. Omcheni (the First) is the pioneer of folklore and epic legend, which the Evens descended from. At 
the same time, his wife-swan is a mythological progenitor of the Evens.

The poem "Омчэни" was the first lyricepic work in the Even literature. Thus, carefully treating the Even culture and developing it, the poet tries to preserve the spirituality of his people.

Uluro Ado also became the author of the first poems in Yukaghir literature. Among Yukaghirs "no cosmogonic or ethnological myths about the nature of fire are recorded" (Zhukova, 1996: 54). And Uluro Ado himself creates a fairy tale and his first poem "The Man and the Red Beast". Having tamed the fire, the ancient man changed not only himself and his existence, but all his life on earth. Therefore, this topic excited the minds of many peoples. In the poem by Uluro Ado, the act of heroism is in overcoming man's own fear and ignorance, it is Man who conquers and asserts himself. The poet chants a hymn to Man, the genre itself orients to poetization and romanticization of the described images. The composition of the poem consists of three parts these are three meetings of the man with fire. At first the man is portrayed as resembling a beast and at the same time a small child, he is timid, shy and naive. Ancient people spiritualized the forces of nature; therefore, the fire is perceived as the Red Beast. It is endowed with all the habits of a wild beast: it is vigorous, fast, fearsome and crushes everything on its way. Fire flies out of the forest like a huge fierce shaggy beast, destroying everything on its way. Running away from it in horror, a man throws a bone which he was gnawing at it. But the fire disappears in the water, and the man makes a conclusion that, as it turns out, there is something what the fire is afraid of. And when he returns, he finds his bone and learns that the Beast can give tasty food to the man. During the third meeting with the fire, the man will know about the heat that the fire gives. He finds a small flame, which he feeds and tames, and they become friends. And the spirit of fire -
Meru is honored by the people most of all and immensely worshiped.

Fire for the peoples of the north means life. It not only feeds and gives heat, but it is also endowed with various magical properties: the power of purification and protection from evil spirits. Fire is a frequent image in the Yukaghir literature, it is a symbol of life, man and his deeds (Okorokova, 2011: 96). The poem by Uluro Ado is dedicated to children and written in the easy style, beautiful images are created, the adventures of characters are described with sparkling humor.

Literary works based on ancient traditions "Nunni", "The Hubble of Aurora", "Edilvei", where the historical and ethnographic motives are intensified, are clearly distinguished in the poems by Uluro. The poet enlivens the ancient pages of the history of his native people, depicting ceremonial holidays, traditions, dances and songs. The poem "Edilvei" is based on the ancient Yukaghir legend, which the author himself wrote down from the words of the old people in 1963. As well as Omcheni, Edilvei is the ancestor of the Yukaghirs, a national hero. He is portrayed as a strongman, jumping over rivers, and an unbeatable fighter. But the author demonstrates two births of the man, this is his becoming a hero and his moral maturity. Losing his soul several times, he finds himself in the hardest trials and struggle, marries and becomes a full-fledged, settles down person, a respected leader. Thus, in the literary version, combining epic and modern traditions, the poet enriches the content of the legend. And in poetics, the author follows the traditions of folk art. Detailed descriptions of the characters' portraits and nature, which abound in folklore figures of speech are represented detailed similes, epithets, hyperboles, repetitions, parallelisms, etc. Ritual actions - hunting, military, wedding, as well as songs and dances of the people are also described in detail. At the same time, the poet raises the global human 
problems of modern times - war and peace, struggle and tolerance. In general, it is the voice, the faith and aspirations of the people about the beautiful future embodied in the poetic word by Uluro Ado.

Omcheni and Edilvei are the ancestors of their peoples, their names are common, and the stories about their actions and deeds are widely spread in ancient myths and legends. Using and depicting the image of the folk heroes poets V. Lebedev and Uluro Ado created the type of a national hero, which is also of significance in the modern life of peoples.
Thus, in the poetry of the young literatures of the peoples of the North, the genre of poem occupies the main place from the time of its origin. The poem by V. Lebedev and Uluro Ado is originated from two sources. This, above all, is following the epic traditions of oral folk art - the basis of their works are plots, images and folklore poetics. At the same time, the role of Russian literature and the modern life of society in the development of the genre of the poem is important, the poets think about the fate of their peoples and the problems of mankind.

\section{References}

Lebedev, V. (1963). Omcheni. Yakutsk, Yakutsk Publishing House, 68 p.

Lebedeva, Zh.K. (1981). Arkhaicheskii epos evenov [Archaic Epos of the Evens]. Novosibirsk, Nauka, 158 p.

Myreeva, A.N. (1980). O zapevakh evenkiiskikh skazanii [On the Introductions to the Evenki Legends], In Voprosy iazyka i fol'klora narodnostei Severa [Issues of the Language and Folklore of the Peoples of the North]. Yakutsk, Yakutsk Branch of Siberian Branch of the Academy of Science of the USSR, 93-102.

Okorokova, V.B. (2011). Poetika iukagirskogo romana [Poetics of the Yukaghir Novel]. Germany, Lambert Publishing, $250 \mathrm{p}$.

Reshetnikova, A.P. (2005). Fond siuzhetnykh motivov i muzyka olonkho v etnograficheskom kontekste [Storylines Fund and Olonkho Music in Ethnographic Context]. Yakutsk, Bichik, 408 p.

Toburokov, N.N. (1991). Problemy sravnitel'nogo stikhovedeniia (na primere sovetskoi poezii tiurkoiazychnykh narodov Sibiri) [Issues of Comparative Study of Poetry (Exemplified by the Soviet Poetry of Turkic-Speaking Peoples of Siberia)]. Moscow, Nauka, 179 p.

Uluro Ado (2013). Izbrannoe [Selected Works]. Yakutsk, Bichik, 350 p.

Zhukova, L.N. (1996). Religiia iukagirov. Iazycheskii panteon. [Yukaghir Religion. Pagan Pantheon]. Yakutsk, YSU Publishing House, 112 p. 


\title{
Особенности жанра поэмы в литературах народов Севера
}

\author{
В.Б. Окорокова, А.А. Винокурова \\ Северо-Восточный федеральный университет \\ им. М.К. Аммосова \\ Россия, 677000, Якутск, ул. Белинского, 58
}

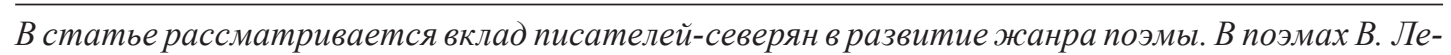
бедева, Улуро Адо, ставших первыми поэтами в эвенской и юкагирской литературах, соединены эпические традиции народов с достижениями современной отечественной литературы. $B$ современной поэзии литератур народов Севера усиливаются мифологические и фольклорные мотивы, в иелом интерес к истории родных народов. В сохранении и возрождении традииий устного народного творчества и начиональной культуры писатели Севера занимают основное место. Но вместе с тем поэмы авторов перекликаются с проблемами человечества, они актуальны и развиваются в русле всей современной литературы.
\end{abstract}

Ключевые слова: литература народов Севера, жанр, поэма, сюжет, образ, фольклорные традищии.

Статья поддержана грантом РГНФ № 17-06-18020 по проекту научно-педагогической экспедиции «Влияние этнокультурных традиций кочевых народов, на развитие личности обучающчихся».

Научная специальность: 10.01.00 - литературоведение. 